\title{
Biological/Chemopreventive Activity of Stilbenes and their Effect on Colon Cancer
}

\author{
Author \\ Agnes M. Rimando ${ }^{1}$, Nanjoo Suh ${ }^{2,3}$ \\ Affiliation \\ United States Department of Agriculture, Agricultural Research Service, Natural Products Utilization Research Unit, \\ University, MS, USA \\ Department of Chemical Biology, Ernest Mario School of Pharmacy, Rutgers, The State University of New Jersey, \\ Piscataway, NJ, USA \\ The Cancer Institute of New Jersey, New Brunswick, NJ, USA
}

Key words

- resveratrol

- stilbenes

- colon cancer

- inflammation

received May 7, 2008

revised July 21,2008

accepted July 30, 2008

\section{Bibliography}

DOI 10.1055/s-0028-1088301 Planta Med 2008; 74: 1635-

1643

(c) Georg Thieme Verlag KG Stuttgart · New York

Published online October 8 , 2008

ISSN 0032-0943

\section{Correspondence}

Prof. Nanjoo Suh

Department of Chemical Biology

Ernest Mario School of

Pharmacy

Rutgers, The State University of

New Jersey

164 Frelinghuysen Road

Piscataway

NJ 08854

USA

Tel.: +1-732-445-3400 (x226)

Fax: +1-732-445-0687

nsuh@rci.rutgers.edu

\section{Abstract \\ $\nabla$}

Colon cancer is one of the leading causes of cancer death in men and women in Western countries. Epidemiological studies have linked the consumption of fruits and vegetables to a reduced risk of colon cancer, and small fruits are particularly rich sources of many active phytochemical stilbenes, such as resveratrol and pterostilbene. Recent advances in the prevention of colon cancer have stimulated an interest in diet and lifestyle as an effective means of intervention. As constituents of small fruits such as grapes, berries and their products, stilbenes are under intense investigation as cancer chemopre- ventive agents. One of the best-characterized stilbenes, resveratrol, has been known as an antioxidant and an anti-aging compound as well as an anti-inflammatory agent. Stilbenes have diverse pharmacological activities, which include cancer prevention, a cholesterol-lowering effect, enhanced insulin sensitivity, and increased lifespan. This review summarizes results related to the potential use of various stilbenes as cancer chemopreventive agents, their mechanisms of action, as well as their pharmacokinetics and efficacy for the prevention of colon cancer in animals and humans.

\section{Introduction \\ $\nabla$}

Predicted death from colon cancer is estimated to be almost 50,000 in the U.S.A. in 2008, making colon cancer the second leading cause of death among all cancer types for men and women in the U.S.A. (American Cancer Society Facts and Fig. 2008). With increasing awareness of disease prevention, not only for colon cancer, changes in diet and lifestyle have received much attention as an effective means of intervention of disease development. Experts allude to diets rich in fruits and vegetables as a key for keeping healthy. Certain groups of compounds, such as polyphenols, have gained popularity as health beneficial constituents in edible plants. Over the past decade, there have been increasing applications for naturally derived phytochemicals as anti-inflammatory and cancer chemopreventive agents [1], [2], [3], [4].

Stilbenes or stilbenoids are a well-known class of naturally occurring phytochemicals. Stilbenes bear the core structure of 1,2-diphenylethylene ( Table 1). These compounds are stress metabolites, produced in the leaves as well as in sap- wood in response to fungal infection [5], [6]. Although known as plant defense compounds, these phytochemicals have an enormous diversity of effects on biological and cellular processes applicable to human health. The biological effects of a well-characterized stilbene, resveratrol, include its role as an inducer of cell differentiation, a mediator of anti-inflammatory action and its effects as an antioxidant and anti-aging agent [3], [7], [8], [9], [10].

The distribution of stilbenes in the plant kingdom is wide. Resveratrol, for example, is found in small fruits such as grapes and Vaccinium berries [10], [11], peanuts [12] and in Polygonum species [13]. Stilbenes structurally related to resveratrol have been found in a variety of foods as well as in medicinal plants ( $\bullet$ Table 1 ). Similar to resveratrol, these phytochemicals have a multitude of biological activities. Some in vitro and in vivo activities related to cancer are provided in - Table 1.

The demonstrated pharmacological properties of naturally occurring stilbenes have inspired the synthesis of analogues in efforts to improve activity. For example, tamoxifen, with the chemical 


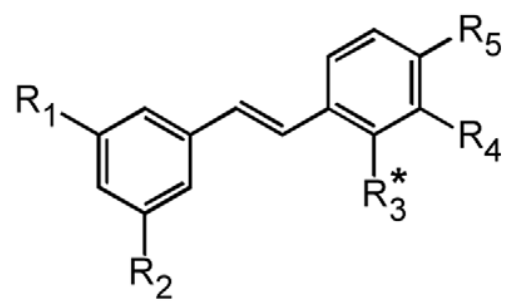

Table 1 Naturally-occurring stilbenes

\begin{tabular}{|c|c|c|c|c|c|c|}
\hline Name & $\mathbf{R}_{1}$ & $\mathbf{R}_{\mathbf{2}}$ & $\mathbf{R}_{\mathbf{4}}$ & $\mathbf{R}_{\mathbf{5}}$ & Plant Source & Anti-cancer related activity \\
\hline Astringin & OGluc & $\mathrm{OH}$ & $\mathrm{OH}$ & $\mathrm{OH}$ & Picea spp. [94] & $\begin{array}{l}\text { Inhibits DMBA-induced lesions in mouse } \\
\text { mammary glands [95] }\end{array}$ \\
\hline $\begin{array}{l}\text { Desoxy- } \\
\text { rhapontigenin }\end{array}$ & $\mathrm{OH}$ & $\mathrm{OH}$ & $\mathrm{H}$ & $\mathrm{OCH}_{3}$ & Rheum spp. [96], [97] & $\begin{array}{l}\text { Inhibits human tumor cell lines, A- } 549 \text {, } \\
\text { SK-OV-3, SK-MEL-2, XF-498 and } \\
\text { HCT15 [98]; Inhibits CYP } 1 \text { A } 1 \text { and 1B1 [58] }\end{array}$ \\
\hline Isorhapontigenin & $\mathrm{OH}$ & $\mathrm{OH}$ & $\mathrm{OCH}_{3}$ & $\mathrm{OH}$ & Picea spp. [94] & $\begin{array}{l}\text { Estrogenic in breast cancer cells MCF-7 } \\
\text { or T-47 D [99] }\end{array}$ \\
\hline Isorhapontin & OGluc & $\mathrm{OH}$ & $\mathrm{OCH}_{3}$ & $\mathrm{OH}$ & Picea spp. [94] & $\begin{array}{l}\text { Estrogenic in breast cancer cells MCF-7 } \\
\text { or T-47 D [99] }\end{array}$ \\
\hline Oxyresveratrol & $\mathrm{OH}$ & $\mathrm{OH}$ & $\mathrm{H}$ & $\mathrm{OH}$ & Morus spp. [100] & $\begin{array}{l}\text { Cytotoxic in human lung and colon cancer } \\
\text { cells [101] }\end{array}$ \\
\hline $\begin{array}{l}\text { Piceatannol } \\
\text { (Astringenin) }\end{array}$ & $\mathrm{OH}$ & $\mathrm{OH}$ & $\mathrm{OH}$ & $\mathrm{OH}$ & $\begin{array}{l}\text { Picea spp. [94], } \\
\text { Rheum undulatum [97] }\end{array}$ & $\begin{array}{l}\text { Inhibits human leukemia cell line U937 } \\
\text { [102] and human bladder cancer cells } \\
{[103]}\end{array}$ \\
\hline Piceid (Polydatin) & OGluc & $\mathrm{OH}$ & $\mathrm{H}$ & $\mathrm{OH}$ & Vitis vinifera [104] & \\
\hline Pinostilbene & $\mathrm{OH}$ & $\mathrm{OCH}_{3}$ & $\mathrm{H}$ & $\mathrm{OH}$ & Pinus sibirica [105] & $\begin{array}{l}\text { Inhibits cytochromes P450 1A1, 1A2, 1B1, } \\
\text { and } 2 \mathrm{E} 1 \text { [57], [58] }\end{array}$ \\
\hline Pinostilbenoside & $\mathrm{OH}$ & $\mathrm{OCH}_{3}$ & $\mathrm{H}$ & OGluc & Pinus spp. [106] & \\
\hline Pinosylvin & $\mathrm{OH}$ & $\mathrm{OH}$ & $\mathrm{H}$ & $\mathrm{H}$ & $\begin{array}{l}\text { Alnus crispa [107], } \\
\text { Pinus resinosa [108] }\end{array}$ & $\begin{array}{l}\text { Inhibits human lymphoblastoid cell lines } \\
\text { Molt and Raji [109] }\end{array}$ \\
\hline $\begin{array}{l}\text { Pinosylvin } \\
\text { monomethylether }\end{array}$ & $\mathrm{OH}$ & $\mathrm{OCH}_{3}$ & $\mathrm{H}$ & $\mathrm{H}$ & $\begin{array}{l}\text { Alnus crispa [107], } \\
\text { Pinus resinosa [108] }\end{array}$ & \\
\hline Pterostilbene & $\mathrm{OCH}_{3}$ & $\mathrm{OCH}_{3}$ & $\mathrm{H}$ & $\mathrm{OH}$ & $\begin{array}{l}\text { Vitis vinifera [110], } \\
\text { Vaccinium spp. [11] } \\
\text { Pterocarpus spp. [111] }\end{array}$ & $\begin{array}{l}\text { Inhibits azoxymethane-induced ACF [51]; } \\
\text { Inhibits cytochromes P450 1A1, 1A2, 1B1, } \\
\text { and 2E1 [57], [58] }\end{array}$ \\
\hline Resveratrol & $\mathrm{OH}$ & $\mathrm{OH}$ & $\mathrm{H}$ & $\mathrm{OH}$ & $\begin{array}{l}\text { Vitis vinifera [5], Arachis } \\
\text { hypogaea [12], } \\
\text { Polygonum spp. [13] }\end{array}$ & $\begin{array}{l}\text { Numerous studies, Inhibits cytochromes } \\
\text { P450 1A1, 1A2, 1B1, and 2E1 [57], [58] }\end{array}$ \\
\hline $\begin{array}{l}\text { Resveratrol } \\
\text { trimethylether }\end{array}$ & $\mathrm{OCH}_{3}$ & $\mathrm{OCH}_{3}$ & $\mathrm{H}$ & $\mathrm{OCH}_{3}$ & Virola elongata [112] & $\begin{array}{l}\text { Anti-proliferative activity towards } \\
\text { DU-145, LNCaP, M- } 14 \text { and KB cells lines } \\
\text { [113]; Inhibits cytochromes P450 1A2, } \\
\text { 2E1 [57] }\end{array}$ \\
\hline Resveratroloside & $\mathrm{OH}$ & $\mathrm{OH}$ & $\mathrm{H}$ & OGluc & Rhei palmati [114] & \\
\hline $\begin{array}{l}\text { Rhaponticin } \\
\text { (Rhapontin) }\end{array}$ & OGluc & $\mathrm{OH}$ & $\mathrm{OH}$ & $\mathrm{OCH}_{3}$ & Rheum undulatum [97] & $\begin{array}{l}\text { Inhibits human tumor cell lines A-549, } \\
\text { SK-OV-3, SK-MEL-2, XF-498 and HCT15 } \\
\text { [98] }\end{array}$ \\
\hline Rhapontigenin & $\mathrm{OH}$ & $\mathrm{OH}$ & $\mathrm{OH}$ & $\mathrm{OCH}_{3}$ & Rheum spp. [96], [97] & $\begin{array}{l}\text { Inhibits human tumor cell lines A-549, } \\
\text { SK-OV-3, SK-MEL-2, XF-498 and HCT15 } \\
\text { [98] }\end{array}$ \\
\hline
\end{tabular}

${ }^{*} \mathrm{R}_{3}=\mathrm{H}$ for all the stilbenes except for oxyresveratrol where $\mathrm{R}_{3}=\mathrm{OH}$; DMBA, 7,12-dimethylbenz $[a]$ anthracene.

core structure of 1,1,2-triphenylethylene (which contains the stilbene skeleton), proved to be highly efficacious for the prevention and treatment of breast cancer [14]. A synthetic stilbene, 3'hydroxystilbene, was markedly more effective than resveratrol in inhibiting the growth of sensitive and resistant leukemia cells HL60, K562, HUT78, and HUT78B3 [15]. 3,4,5-Trimethoxy-4'bromo-cis-stilbene inhibited human colon cancer cell proliferation much more effectively than resveratrol, and this trimethoxystilbene is considered a good colon cancer chemopreventive or chemotherapeutic agent [16]. Although many synthetic stilbene analogues active against various types of cancer have been generated, this review will mainly focus on resveratrol and some of its naturally-occurring analogues as related to colon cancer preventive activity.

\section{Mechanisms of Action of Stilbenes \\ $\nabla$}

In vitro mechanisms of action of the most representative stilbene, resveratrol, have been extensively discussed in numerous reports and reviews [9], [17], [18], [19]. Resveratrol and other related stilbenes suppress the proliferation of a wide variety of cultured cancer cells, including colon, prostate, breast, pancreas, ovary, melanoma, head and neck, and others [9], [17], [19], [20]. 
Several key mechanisms of action include inhibition of the transcription factor NF- $\kappa$ B [9], regulation of cytochrome P450 enzymes [21], [22], activation of nuclear receptors such as estrogen receptors (ERs) [23], [24] and peroxisome proliferator-activated receptors (PPARs) [25], [26], [27], inhibition of expression and activity of inflammation-related enzymes such as cyclooxygenases [17], [19], [28], and regulation of sirtuins [7], [29], [30]. More details are summarized below.

\section{Growth inhibition and induction of apoptosis by stilbenes}

An extensive literature on growth inhibition and induction of apoptosis of stilbenes has been documented largely with its most representative stilbene, resveratrol. The growth-inhibitory effects of resveratrol are thought to be mediated mainly through cell-cycle arrest induced by up-regulation of p21, p27, p53 and Bax, and down-regulation of survivin, cyclin D1, cyclin E, Bcl-2, Bcl-xL and clAPs [9], [31]. Resveratrol induces apoptosis by upregulating the expression of Bax, Bak, PUMA, Noxa, Bim, p53, TNF-related apoptosis-inducing ligand (TRAIL), TRAIL-R1/DR4 and TRAIL-R2/DR5 and simultaneously down-regulating the expression of $\mathrm{Bcl}-2, \mathrm{Bcl}-\mathrm{xL}, \mathrm{Mcl}-1$ and survivin [32]. Using HCT116 colon cancer cell lines with different status of Bax and p53 $\left(\mathrm{Bax}^{+} /-, \mathrm{Bax}-/-, \mathrm{p} 53+/+\right.$, and $\left.\mathrm{p} 53-/-\right)$, it was found that resveratrol induced apoptosis more strongly in $\mathrm{Bax}+/-$ and $\mathrm{p} 53+/+$ cells than in their knockout counterparts (Bax-/- and p53-/-), respectively. Furthermore, the lower apoptosis sensitivity of the knockout cells (Bax-/- and p53-/-) was correlated with the relatively reduced processing of caspase- 6 and lamin A cleavage [33]. Resveratrol induces both Fas/Fas ligand-mediated [34], [35] and Fas-ligand independent apoptosis [36], [37], p53 and DNA repair systems [18]. Resveratrol also potentiates the apoptotic effects of cytokines, chemotherapeutic agents and $\gamma$-radiation [38]. However, resveratrol analogues, such as 3,4,5-trihydroxy-trans-stilbene, are known to induce extensive apoptosis by a Fas-associated death domain (FADD) protein-dependent mechanism without involving the known death ligands CD95 ligand (CD95 L), tumor necrosis factor $\alpha$ (TNF $\alpha$ ) or TRAIL, suggesting a difference between the apoptotic activity of resveratrol and its analogues [39], [40].

Several kinase-signaling cascades have been shown to be involved in growth inhibition and apoptosis effects mediated by resveratrol and related stilbenes. The key survival pathways are the mitogen-activated protein kinase (MAPK) and phosphatidylinositol-3 kinase (PI3K)/AKT [27], [41], [42]. Resveratrol targets the MAPK pathways [41], [43] and inhibits activation of PI3K via both hormone receptor-dependent and -independent mechanisms [20], [27], [44], [45], indicating that resveratrol promotes apoptosis by blocking expression of anti-apoptotic proteins and by regulating upstream survival signal transduction such as MAPK and PI3K/AKT pathways.

\section{PPAR $\alpha$ - and PPAR $\gamma$-mediated action of stilbenes}

PPARs are ligand-dependent transcription factors, which belong to the nuclear receptor family. PPAR $\alpha$ - and PPAR $\gamma$-receptors mediate the metabolism and disposition of lipids and fatty acids [25], [26]. PPAR $\gamma$ involvement in resveratrol action was determined by ligand-dependent activation and increased expression of PPAR $\gamma$ coactivator PGC- $1 \alpha$ and SIRT1 [26]. Resveratrol failed to modulate polyamine metabolism in the presence of PPAR $\gamma$ mutant or in PPAR $\gamma$ dominant negative cells [26], suggesting that resveratrol acts through PPAR $\gamma$-dependent mechanisms in polya- mine metabolism. Resveratrol reduced infarct volume after middle cerebral artery occlusion in PPAR $\alpha$ wild-type mice, while resveratrol failed to protect the brain in PPAR $\alpha$ knockout mice, indicating that resveratrol protected the brain through a PPAR $\alpha$ dependent mechanism [46]. However, using an assay for the activation of endogenous PPAR $\alpha$ in H4IIEC3 cells, Rimando et al. investigated the activation of PPAR $\alpha$ with resveratrol and its three analogues, pterostilbene, piceatannol, and resveratrol trimethyl ether, and showed that pterostilbene, but not resveratrol, piceatannol, or resveratrol trimethyl ether, acts as a PPAR $\alpha$ agonist [25].

\section{ER-mediated action of stilbenes}

Resveratrol binds and activates $\operatorname{ER} \alpha$ as well as $\operatorname{ER} \beta$ [23], [24], [47]. Although binding of resveratrol to ERs is low compared to estradiol, it functions as a full agonist [24], [47], [48]. Resveratrol acts as a selective estrogen receptor modulator (SERM), and the effects of resveratrol depend on the cell type and target organs as well as on the presence of endogenous estrogens [20], [23], [24], [45], [47]. It still needs to be determined whether the estrogenic effects of resveratrol and related stilbenes are physiologically relevant and whether some of the health effects of stilbenes stem from their estrogenic action. Since ER- $\beta$ is present in the colon and is suggested to play a role in the inhibitory effect of estrogens on colon cancer [49], it will be interesting to determine whether stilbenes prevent colon cancer via estrogenic action and interaction with the ER- $\beta$ in the colon.

\section{Anti-inflammatory action of stilbenes}

Mechanisms of the anti-inflammatory effects of stilbenes include (a) inhibition of synthesis and release of pro-inflammatory mediators, (b) modification of eicosanoid synthesis, (c) inhibition of activated immune cells, and (d) inhibition of inducible nitric oxide synthase (iNOS), cyclooxygenase-1 (COX-1) or cyclooxygenase-2 (COX-2) [17], [19], [28], [50], [51]. Resveratrol as well as related stilbenes have been shown to reduce inflammation via inhibition of prostaglandin production, cyclooxygenase-2 activity, NF- $\mathrm{KB}$ activity or activator protein-1 (AP-1) [28], [32], [52]. Resveratrol also inhibits inflammatory processes by regulating upstream protein kinases such as I $\mathrm{KB} \alpha$ kinase [50], [53], JNK [54], MAPK [41], [43], PKC [43], PI3K-AKT [45], [55] and p38 [55]. Consequently, resveratrol and related stilbenes downregulate several key inflammatory markers such as COX-2, 5LOX, iNOS, as well as inflammatory mediators such as TNF- $\alpha$, VEGF, IL-1, IL-6, and IL-8 [8], [19], [32]. Pterostilbene, a naturally occurring stilbene in blueberries, was shown to decrease expression of inflammatory genes, such as iNOS in the colonic crypts and ACF in rats, suggesting that the anti-inflammatory properties of stilbenes may be critical in the prevention of colon tumorigenesis [51].

\section{Other mechanisms of stilbene action}

Cytochrome P450 enzymes, such as CYP1A1 and 1B1, are responsible for the biotransformation of certain procarcinogens to ultimate carcinogens, and therefore, the inhibitory effect of resveratrol and its derivatives on cytochromes $\mathrm{P} 450$ has been investigated as possible chemopreventive mechanisms of action [56], [57], [58]. It should be noted, however, that these enzymes also play a role in the detoxification of carcinogens. Resveratrol, desoxyrhapontigenin, pterostilbene, pinostilbene and resveratrol trimethyl ether were shown to inhibit enzyme activities of cytochrome P450 1A1, 1A2, 1B1, and 2E1 ( Table 1). Results from 
these studies indicate that trans-resveratrol derivatives with methoxy groups substituting for the hydroxy groups exhibit a remarkably stronger inhibition of CYP $1 \mathrm{~A} 1$ than resveratrol [57], [58].

Other biological activities of resveratrol such as anti-invasion or anti-angiogenesis have also been reported [59], [60], [61]. Interestingly, resveratrol has been found to exert both pro- and antiangiogenic effects. Pro-angiogenic effects are noted in the periinfarct myocardium, whereas resveratrol is known to inhibit angiogenesis in tumors [62]. In another study, resveratrol and various synthetic trans-resveratrol derivatives were tested as antiangiogenic agents [59]. In this study, 3,5,4'-trimethoxystilbene inhibited blood vessel growth and caused the disappearance of pre-existing blood vessels in the area vasculosa of the chick embryo. 3,5,4'-Trimethoxystilbene was shown to be an anti-angiogenic agent 30 to 100 times more potent than resveratrol in inhibiting endothelial cell proliferation, sprouting, collagen gel invasion, and morphogenesis [59].

In addition, resveratrol activates sirtuin deacetylases, extends the lifespan of lower organisms, and has a protective effect in rodent models of stress and disease [7], [26], [63]. Treatment of mice with resveratrol significantly increased their aerobic capacity, and the effect was largely explained by the decrease in PGC- $1 \alpha$ acetylation and an increase in PGC- $1 \alpha$ activity [7], [26], [29]. This mechanism is consistent with resveratrol being a known activator of the protein deacetylase, SIRT1 [29]. Importantly, resveratrol (a) increases insulin sensitivity, (b) reduces insulin-like growth factor-1 (IGF-I) levels, (c) increases AMP-activated protein kinase (AMPK) and PGC- $1 \alpha$ activity, and (d) improves motor function in mice, suggesting that resveratrol shifts the physiology of middle-aged mice on a high-calorie diet to increased survival and longer lifespan [7]. Other interesting activities of stilbenes, such as neuroprotection and anti-bacterial action, suggest that stilbenes may be useful not only for the inhibition of cancer but also for the treatment of diabetes, cardiovascular diseases as well as neurological and other chronic diseases.

\section{Pharmacokinetics of Stilbenes}

$\nabla$

Although there are numerous in vitro studies with stilbenes (particularly resveratrol), absorption and bioavailability of these compounds is important in determining whether biologically active concentrations are achieved in vivo and whether the com- pound reaches specific target sites. In a study involving six human volunteers, $\geq 70 \%$ absorption of the radioactivity from a $25 \mathrm{mg}$ oral dose of ${ }^{14} \mathrm{C}$-resveratrol was observed. However, resveratrol was rapidly metabolized, leaving only very small amounts of unconjugated resveratrol in the systemic circulation. The peak plasma levels of resveratrol and metabolites was $491 \pm 90 \mathrm{ng} / \mathrm{mL}$ (half-life $9.2 \pm 0.6 \mathrm{~h}$ ) in humans, but unchanged resveratrol comprised less than $5 \mathrm{ng} / \mathrm{mL}$ [64].

In another study, resveratrol was given orally to healthy human subjects ( $25 \mathrm{mg} / 70 \mathrm{~kg}$ ) in three different liquid matrices: vegetable juice, white wine and white grape juice [65]. Resveratrol was found in the serum predominantly as glucuronide and sulfate conjugates. The highest level of resveratrol was reached at about 30 min after consumption for all the three matrices, and the levels declined rapidly thereafter. The absorption of resveratrol was more effective in grape juice than in wine or vegetable juice. The peak plasma concentration of 10 to $40 \mathrm{nmol} / \mathrm{L}$ (for resveratrol and two other phenolics included in this study) is lower than the concentrations of 5 to $100 \mu \mathrm{mol} / \mathrm{L}$ necessary for in vitro biological activity [65]. In yet another study, following oral or intraperitoneal administration of resveratrol to rats and mice, transresveratrol 3-O-glucuronide and trans-resveratrol 3-sulfate were found as the most abundant metabolites and no unconjugated resveratrol was detected in urine or serum samples [66]. The voluminous literature reporting powerful in vitro anticancer and anti-inflammatory effects of the free polyphenols seems irrelevant, given that these compounds get readily conjugated [65], although $\beta$-glucuronidase and sulfatase may deconjugate glucuronide and sulfate metabolites in target tissues.

Resveratrol has a short plasma half-life ( $10.3 \mathrm{~min}$ in mice, $14.4 \mathrm{~min}$ in rabbits) compared to some of its analogues ( Table 2). Pharmacokinetic studies with pterostilbene, piceatannol, pinosylvin, and rhapontigenin show that these stilbenes are well absorbed [67], [68]. Similar to resveratrol, these compounds are also glucuronidated, but they reportedly have longer plasma half-lives than resveratrol ( $\bullet$ Table 2 ). The values for the volume of distribution for these stilbenes are high, indicating that they are highly distributed into tissues. These stilbenes are mainly excreted via non-renal routes, predominantly via biliary elimination. The serum concentration of pterostilbene glucuronide was found to initially decrease followed by an increase $1-2$ hours post-administration, which indicated enterohepatic recirculation of this metabolite [67]. Similarly, enterohepatic recycling of resveratrol has been observed; i.e., plasma concentrations in-

\begin{tabular}{|c|c|c|c|c|}
\hline Compound & Test animal & $\begin{array}{l}\text { Dose, Route of } \\
\text { administration }\end{array}$ & $\begin{array}{l}\text { Plasma half-life } \\
\left(T_{1 / 2}\right)\end{array}$ & Reference \\
\hline Piceatannol & Rat & $\begin{array}{l}10 \mathrm{mg} / \mathrm{kg} \mathrm{BW} \text {, } \\
\text { intravenous }\end{array}$ & $4.23 \mathrm{~h}$ & [68] \\
\hline Pinosylvin & Rat & $\begin{array}{l}10 \mathrm{mg} / \mathrm{kg} \mathrm{BW} \text {, } \\
\text { intravenous }\end{array}$ & $49.2 \mathrm{~min}$ & [68] \\
\hline Pterostilbene & Mouse & $\begin{array}{l}20 \mathrm{mg} / \mathrm{kg} \mathrm{BW} \text {, } \\
\text { intravenous }\end{array}$ & $77.9 \mathrm{~min}$ & [115] \\
\hline Pterostilbene & Rat & $\begin{array}{l}20 \mathrm{mg} / \mathrm{kg} \mathrm{BW} \text {, } \\
\text { intravenous }\end{array}$ & $1.73 \mathrm{~h}$ & [67] \\
\hline Resveratrol & Mouse & $\begin{array}{l}20 \mathrm{mg} / \mathrm{kg} \mathrm{BW} \text {, } \\
\text { intravenous }\end{array}$ & $10.3 \mathrm{~min}$ & [115] \\
\hline Resveratrol & Rabbit & $\begin{array}{l}20 \mathrm{mg} / \mathrm{kg} \text { BW, } \\
\text { intravenous }\end{array}$ & $14.4 \mathrm{~min}$ & [116] \\
\hline Rhapontigenin & Rat & $\begin{array}{l}10 \mathrm{mg} / \mathrm{kg} \mathrm{BW} \text {, } \\
\text { intravenous }\end{array}$ & $3.0 \mathrm{~h}$ & [68] \\
\hline
\end{tabular}

Table 2 Plasma half-life of stilbenes 
creased 4-8 hours post-administration, after a rapid decline in the plasma level immediately after administration [69]. Prolonged contact and apparent affinity of these stilbenes with the gastrointestinal system may find their use in the prevention and treatment of gastrointestinal diseases such as colon cancer, ulcerative colitis and Crohn's disease.

\section{In Vivo Efficacy Studies of Stilbenes in Animal Models of Colon Cancer \\ $\nabla$}

Although there are many reports describing the in vivo activities of resveratrol and related stilbenes on the prevention of skin [28], [50], [70], [71], [72], esophageal [73], lung [13], and mammary tumorigenesis [60], [74], [75], this review will focus mainly on in vivo activities against colon cancer (summarized in - Table 3). The intriguing link between chronic inflammation and cancer has been the subject of numerous studies for more than a century [76]. In particular, inflammatory conditions, such as ulcerative colitis, increase the risk of colon cancer by 20-fold [77]. Overexpression of pro-inflammatory enzymes, such as iNOS and COX-2, has been reported in human colon cancer [78], [79] and in an azoxymethane (AOM)-induced colon cancer model in animals [80], [81]. More importantly, selective inhibitors of these inflammatory genes are effective in reducing the number of colorectal polyps in humans and in suppressing the formation of AOM-induced hyperplastic aberrant crypt foci (ACF) and colon tumors in rats [81], [82].

Tessitore et al. reported that administration of resveratrol $(0.2 \mathrm{mg} / \mathrm{kg} /$ day $)$ in drinking water to male F344 rats for 100 days, beginning 10 days before AOM treatment, inhibited the formation of ACF preneoplastic lesions of the colonic mucosa [83]. This study showed that resveratrol reduced the number of ACF per colon and abolished the formation of large ACF, which may be due to the mechanisms involving bax and p21 expression [83]. Oral daily administration of resveratrol $(8 \mathrm{mg} / \mathrm{kg}$ body weight) also reduced tumor incidence, tumor size, and ACF formation in the 1,2-dimethylhydrazine-induced colon cancer model in rats [84]. In the Min mouse, a model of multiple intestinal neoplasia, tumors occur predominantly in the small intestine and only a few tumors appear in the colon. Mutant Min mice have been used as a familial adenomatous polyposis (FAP) intestinal neoplasia model [85]. Administration of resveratrol $(0.01 \%$ in drinking water) suppressed the formation of both intestine and colon tumors in Min mice [86]. However, Ziegler et al. reported in another study that mice given resveratrol in the diet at doses of 4,20 , and $90 \mathrm{mg} / \mathrm{kg}$ body weight for 7 weeks had no reduction of intestinal tumors [87]. Using colon adenoma as an end point, Sale et al. indicated that resveratrol and its analogue DMU212 (3,4,5,4'-tetramethoxystilbene) given as $0.2 \%$ in the diet significantly decreased the number of adenomas, whereas $0.05 \%$ of either stilbenes given in the diet did not [88]. Kineman et al. reported that feeding female CF- 1 mice with $20 \%$ transgenic alfalfa containing resveratrol as a glucoside (trans-resveratrol3-O- $\beta$-D-glucopyranoside, approximately $152 \mu \mathrm{g} / \mathrm{g}$ dry weight of transgenic alfalfa) in the diet did not inhibit the number, size, or multiplicity of ACF in the colon of the mice [89]. In contrast, addition of resveratrol-aglycone ( $20 \mathrm{mg} / \mathrm{kg} \mathrm{diet})$ to the basal diet reduced the number of ACF per mouse [89], suggesting that resveratrol glucoside is not effective in preventing colon cancer.

Table 3 In vivo efficacy of stilbenes in animal models of colon cancer

\begin{tabular}{|c|c|c|c|c|}
\hline Compound & Animal model used & $\begin{array}{l}\text { Duration } \\
\text { of study }\end{array}$ & $\begin{array}{l}\text { Endpoint/ } \\
\text { Efficacy }\end{array}$ & Reference \\
\hline $\begin{array}{l}\text { Resveratrol glucoside } \\
\text { ( } 152 \mu \mathrm{g} / \mathrm{g} \text { dry weight of } \\
\text { transgenic alfalfa, } 20 \% \text { in the } \\
\text { diet) }\end{array}$ & $\begin{array}{l}\text { AOM }(5 \mathrm{mg} / \mathrm{kg} B W) \text { induced } \\
\text { ACF in female CF- } 1 \text { mice }\end{array}$ & 5 weeks & No reduction in ACF (size and number) & {$[89]$} \\
\hline $\begin{array}{l}\text { Resveratrol }(20 \mathrm{mg} / \mathrm{kg} \text { in the } \\
\text { diet) }\end{array}$ & $\begin{array}{l}\text { AOM ( } 5 \mathrm{mg} / \mathrm{kg} B W \text { ) induced } \\
\text { ACF in female CF-1 mice }\end{array}$ & 5 weeks & Inhibition of ACF (size and number) & {$[89]$} \\
\hline $\begin{array}{l}\text { Resveratrol ( } 8 \text { mg/kg BW, p.o. } \\
\text { every day) }\end{array}$ & $\begin{array}{l}\text { DMH }(20 \mathrm{mg} / \mathrm{kg} \mathrm{BW}) \text { induced } \\
\text { colon cancer in male Wistar } \\
\text { rats }\end{array}$ & $\begin{array}{l}15 \text { and } 30 \\
\text { weeks }\end{array}$ & $\begin{array}{l}\text { Reduction of tumor incidence and size } \\
\text { (both adenoma and adenocarcinoma), } \\
\text { and ACF with six crypts }\end{array}$ & {$[84],[117]$} \\
\hline Resveratrol ( $0.2 \%$ in the diet) & $\begin{array}{l}\text { Apc }(\text { Min }+) \text { mouse model of } \\
\text { colon cancer }\end{array}$ & $\begin{array}{l}10-14 \\
\text { weeks }\end{array}$ & Decreased adenoma & {$[88]$} \\
\hline $\begin{array}{l}3,4,5,4 \text { ' -Tetramethoxystilbene } \\
\text { (DMU } 212,0.2 \% \text { in the diet) }\end{array}$ & $\begin{array}{l}\text { Apc }(\text { Min }+) \text { mouse model of } \\
\text { colon cancer }\end{array}$ & $\begin{array}{l}10-14 \\
\text { weeks }\end{array}$ & Decreased adenoma & {$[88]$} \\
\hline $\begin{array}{l}\text { Resveratrol }(0,4,20 \text { or } \\
90 \mathrm{mg} / \mathrm{kg} \text { BW in the diet })\end{array}$ & $\begin{array}{l}\text { Apc }(\text { Min }+) \text { mouse model of } \\
\text { colon cancer }\end{array}$ & 7 weeks & $\begin{array}{l}\text { No reduction of intestinal tumors, } \\
\text { no histological changes observed }\end{array}$ & {$[87]$} \\
\hline $\begin{array}{l}\text { Resveratrol }(0.01 \% \text { in the } \\
\text { drinking water) }\end{array}$ & $\begin{array}{l}\text { Apc }(\mathrm{Min}+) \text { mouse model of } \\
\text { colon cancer }\end{array}$ & 7 weeks & $\begin{array}{l}\text { Inhibition of formation of both colon } \\
\text { tumors and intestinal tumors }\end{array}$ & [86] \\
\hline $\begin{array}{l}\text { 3,5,4' -Trimethoxystilbene } \\
\text { (50 mg/kg i.p.) }\end{array}$ & $\begin{array}{l}\text { Colo } 205 \text { xenograft model of } \\
\text { colon cancer }\end{array}$ & 23 days & Reduction of xenograft tumor growth & {$[118]$} \\
\hline $\begin{array}{l}\text { Pterostilbene ( } 40 \mathrm{ppm} \text { in the } \\
\text { diet) }\end{array}$ & $\begin{array}{l}\mathrm{AOM}(15 \mathrm{mg} / \mathrm{kg} \mathrm{BW}) \text { induced } \\
\text { colonic ACF in male Fischer } \\
\text { rats }\end{array}$ & 8 weeks & $\begin{array}{l}\text { Reduction of the number of ACF/colon } \\
\text { and multiple crypts }\end{array}$ & {$[51]$} \\
\hline $\begin{array}{l}\text { Resveratrol }(0.2 \mathrm{mg} / \mathrm{kg} / \text { day in } \\
\text { drinking water }) \text {, beginning } 10 \\
\text { days before AOM treatment }\end{array}$ & $\begin{array}{l}\mathrm{AOM}(15 \mathrm{mg} / \mathrm{kg} \mathrm{BW}) \text { induced } \\
\text { colonic } \mathrm{ACF} \text { in male Fischer } \\
\text { rats }\end{array}$ & 100 days & $\begin{array}{l}\text { Reduction the number of ACF/colon and } \\
\text { abolished large ACF }\end{array}$ & [83] \\
\hline $\begin{array}{l}\text { Resveratrol ( } 10 \mathrm{mg} / \mathrm{kg} / \text { day, } \\
\text { p. o. every day) }\end{array}$ & $\begin{array}{l}\text { TNBS ( } 30 \text { mg per animal) } \\
\text { induced chronic colonic } \\
\text { colitis in male Wistar rats }\end{array}$ & 14 days & $\begin{array}{l}\text { Attenuation of the damage in chronic } \\
\text { colitis, decreased oxidative events } \\
\text { associated to colonic injury }\end{array}$ & {$[119]$} \\
\hline
\end{tabular}


We have recently shown that dietary pterostilbene, a naturally occurring stilbene in blueberries, caused suppression of ACF formation in the AOM-induced colon cancer model in rats, which may be due to a decreased expression of inflammatory genes, such as iNOS, in the colonic crypts and ACF [51].

\section{Epidemiology|Human Intervention Studies \\ $\nabla$}

The discovery of anticarcinogenic activity of resveratrol [90], constituents of grapes and red wine, has stimulated interest in resveratrol and its derivatives as potential chemopreventive and/or chemotherapeutic agents. However, epidemiological data on stilbenes and cancer prevention are limited. A study by Zern and colleagues reported effects of grape polyphenols on plasma lipids, inflammatory cytokines, and oxidative stress [91]. Twenty-four premenopausal and 20 postmenopausal women were randomly assigned to consume $36 \mathrm{~g}$ of a lyophilized grape powder (LGP) or a placebo for 4 weeks. The LGP used in this trial is rich in flavans, anthocyanins, quercetin, myricetin, kaempferol, and resveratrol. LGP decreased whole-body oxidative stress and levels of plasma TNF- $\alpha$, suggesting that LGP intake positively affected key risk factors for coronary heart disease in both pre- and postmenopausal women through alterations in lipoprotein metabolism, oxidative stress, and inflammatory markers [91].

An analysis of the relation between dietary intake of resveratrol and breast cancer risk used data from a case-control study conducted between 1993 and 2003 in the Swiss Canton of Vaud on 369 cases and 602 controls [92]. A significant inverse relation between intake of resveratrol, but not wine, and breast cancer risk was observed. This was not explained by several potential confounding factors, including detailed allowance for alcohol intake, nor attributable to a non-specific favorable effect of fruit on breast cancer risk [92]. Only a few human colon cancer intervention studies with resveratrol have been reported thus far because most studies were initiated only recently.

Currently, there are 6 clinical studies designed to test the efficacy and toxicity of resveratrol in humans and a few of them are specifically testing resveratrol for prevention and treatment of colon cancer. Initiated in 2004, a phase I single-dose safety and pharmacokinetics clinical study of resveratrol was carried out to study the side effects and dose of resveratrol in preventing cancer in 40 healthy participants [93]. Forty healthy participants (ages 18 to 80 years) were recruited into the study and randomized into four groups (single oral doses of $0.5,1,2.5$, or $5 \mathrm{~g}$ ). In this trial, consumption of resveratrol did not cause serious adverse events. The mean peak plasma level of resveratrol at the highest dose was $2.4 \mu \mathrm{mol} / \mathrm{L}(\mathrm{n}=10)$, and was reached $1.5 \mathrm{~h}$ post-dose. The study reported that the area under the plasma concentration curve (AUC) values for resveratrol 3-sulfate and resveratrol monoglucuronides were 23 times greater than those for resveratrol, and the urinary excretion of resveratrol and its metabolites was rapid [93]. The authors indicated that consumption of a high-dose of resveratrol might be insufficient to elicit systemic levels commensurate with cancer chemopreventive efficacy since cancer chemopreventive effects of resveratrol in cells require at least $5 \mu \mathrm{mol} / \mathrm{L}$ levels. However, the high systemic levels of resveratrol conjugate metabolites may have cancer chemopreventive properties [93]. Another phase I trial initiated by the same group is currently studying repeated dosing of resveratrol in treating patients with colorectal cancer that can be removed by surgery. A total of 20 patients will be accrued for this study. This phase I repeat-dose study of resveratrol in colorectal cancer patients will determine tolerability, target tissue levels and pharmacodynamics of resveratrol.

In a phase I study initiated by the University of California, Irvine in 2005, resveratrol pills at a daily dose of $20 \mathrm{mg}, 80 \mathrm{mg}$ or $160 \mathrm{mg}$ have been given to 12 patients. This trial will define the action of resveratrol on the Wnt signaling pathway. Patients with colon cancer will receive resveratrol and correlative laboratory studies will examine its effects on colon cancer and normal colonic mucosa. The results from this study have not yet been reported. Another phase I study of dietary grape-derived low-dose resveratrol for colon cancer prevention will be initiated by the University of California, Irvine, in 2008; the dietary influence of grapes in colon cancer prevention will be investigated. This study will determine the minimum dietary achievable amount of resveratrol-rich fresh red grapes that is effective in inhibiting Wnt signaling in human colonic mucosa, and this study will determine the minimum amount of resveratrol-rich fresh red grapes needed to exhibit signs of colon cancer prevention. A total of 30 patients will be recruited and the study will be completed in 2010 (see www.clinicaltrials.gov).

Given the interest in resveratrol and its derivatives, it is likely that more studies will be done. More data will soon be available from several current studies on the effects of resveratrol on colon cancer. It will also be important to determine whether other related analogues have anticancer activity with better efficacy and lower toxicity.

\section{Conclusions}

$\nabla$

As constituents of grapes, red wine and small fruits, resveratrol and related stilbenes are under intense investigation as cancer chemopreventive agents. After the landmark studies on prevention of cancer and protection against the detrimental health effects associated with a high-calorie diet in experimental animals, including resveratrol's ability to mimic caloric restriction, the potential impact of stilbenes on human health have elicited considerable public attention. In vitro cell culture experiments as well as preclinical animal studies with resveratrol and related stilbenes suggest a multitude of mechanisms for the pharmacological activity of this group of compounds. Elucidation of mechanisms of action and in vivo efficacy of stilbenes may lead to new approaches for the treatment and prevention of various neoplasias, including colon cancer.

\section{Acknowledgements \\ $\nabla$}

The authors thank Drs. Allan H. Conney and Pavel Kramata from the Department of Chemical Biology for their helpful comments on the manuscript. This work was supported in part by NIH grants and a CINJ New Investigator Award to Nanjoo Suh.

\section{References}

1 Kelloff GJ, Lippman SM, Dannenberg AJ, Sigman CC et al. Progress in chemoprevention drug development: the promise of molecular biomarkers for prevention of intraepithelial neoplasia and cancer - a plan to move forward. Clin Cancer Res 2006; 12: 3661 - 97

2 Khanna D, Sethi G, Ahn KS, Pandey MK, Kunnumakkara AB, Sung B et al. Natural products as a gold mine for arthritis treatment. Curr Opin Pharmacol 2007; 7: 344-51 
3 Gescher AJ. Resveratrol from red grapes - pedestrian polyphenol or useful anticancer agent? Planta Med 2008; 74: 1651 -5

4 Garodia P, Ichikawa H, Malani N, Sethi G, Aggarwal BB. From ancient medicine to modern medicine: ayurvedic concepts of health and their role in inflammation and cancer. J Soc Integr Oncol 2007; 5: 25 - 37

5 Langcake P, Pryce RJ. A new class of phytoalexins from grapevines. Experientia 1977; 33: 151 - 2

6 Hart JH, Shrimpton DM. Role of stilbenes in resistance of wood to decay. Phytopathology 1979; 69: $1138-43$

7 Baur JA, Pearson KJ, Price NL, Jamieson HA, Lerin C, Kalra A et al. Resveratrol improves health and survival of mice on a high-calorie diet. Nature 2006; 444: 337-42

8 Aggarwal BB, Shishodia S, Sandur SK, Pandey MK, Sethi G. Inflammation and cancer: how hot is the link? Biochem Pharmacol 2006; 72: $1605-$ 21

9 Aggarwal BB, Bhardwaj A, Aggarwal RS, Seeram NP, Shishodia S, Takada $Y$. Role of resveratrol in prevention and therapy of cancer: preclinical and clinical studies. Anticancer Res 2004; 24: $2783-840$

10 Baur JA, Sinclair DA. Therapeutic potential of resveratrol: the in vivo evidence. Nat Rev Drug Discov 2006; 5: 493-506

11 Rimando AM, Kalt W, Magee JB, Dewey J, Ballington JR. Resveratrol, pterostilbene, and piceatannol in vaccinium berries. J Agric Food Chem 2004; 52: 4713 - 9

12 Ingham JL. 3,5,4'-Trihydroxystilbene as a phytoalexin from groundnuts (Arachis hypogaea). Phytochemistry 1976; 15: 1791 -3

13 Kimura Y, Okuda $\mathrm{H}$. Resveratrol isolated from Polygonum cuspidatum root prevents tumor growth and metastasis to lung and tumor-induced neovascularization in Lewis lung carcinoma-bearing mice. J Nutr 2001; 131: $1844-9$

14 Jordan VC. Tamoxifen (ICI46,474) as a targeted therapy to treat and prevent breast cancer. Br J Pharmacol 2006; 147: S269 - 76

15 Tolomeo M, Grimaudo S, Di Cristina A, Roberti M, Pizzirani D, Meli M et al. Pterostilbene and 3'-hydroxypterostilbene are effective apoptosisinducing agents in MDR and BCR-ABL-expressing leukemia cells. Int J Biochem Cell Biol 2005; 37: 1709-26

16 Heo YH, Min HY, Kim S, Lee SK. Growth inhibition and G2/M phase cell cycle arrest by 3,4,5-trimethoxy-4'-bromo-cis-stilbene in human colon cancer cells. J Appl Pharmacol 2007; 15: 95 - 101

17 de la Lastra CA, Villegas I. Resveratrol as an anti-inflammatory and anti-aging agent: mechanisms and clinical implications. Mol Nutr Food Res 2005; 49: 405 - 30

18 Gatz SA, Wiesmuller L. Take a break - resveratrol in action on DNA. Carcinogenesis 2008; 29: 321 - 32

19 Das S, Das DK. Anti-inflammatory responses of resveratrol. Inflamm Allergy Drug Targets 2007; 6: 168-73

20 Benitez DA, Pozo-Guisado E, Clementi M, Castellon E, FernandezSalguero PM. Non-genomic action of resveratrol on androgen and oestrogen receptors in prostate cancer: modulation of the phosphoinositide 3-kinase pathway. Br J Cancer 2007; 96: 1595-604

21 Gusman J, Malonne H, Atassi G. A reappraisal of the potential chemopreventive and chemotherapeutic properties of resveratrol. Carcinogenesis 2001; 22: 1111 - 7

22 Guengerich PF, Chun YJ, Kim D, Gillam EM, Shimada T. Cytochrome P450 1B1: a target for inhibition in anticarcinogenesis strategies. Mutat Res 2003; 523-524: $173-82$

23 Bhat KP, Lantvit D, Christov K, Mehta RG, Moon RC, Pezzuto JM. Estrogenic and antiestrogenic properties of resveratrol in mammary tumor models. Cancer Res 2001; 61: 7456-63

24 Gehm BD, McAndrews JM, Chien PY, Jameson JL. Resveratrol, a polyphenolic compound found in grapes and wine, is an agonist for the estrogen receptor. Proc Natl Acad Sci U S A 1997; 94: 14138-43

25 Rimando AM, Nagmani R, Feller DR, Yokoyama W. Pterostilbene, a new agonist for the peroxisome proliferator-activated receptor alpha-isoform, lowers plasma lipoproteins and cholesterol in hypercholesterolemic hamsters. J Agric Food Chem 2005; 53: 3403 - 7

26 Ulrich S, Loitsch SM, Rau O, von Knethen A, Brune B, Schubert-Zsilavecz $M$ et al. Peroxisome proliferator-activated receptor gamma as a molecular target of resveratrol-induced modulation of polyamine metabolism. Cancer Res 2006; 66: 7348-54

27 Harikumar KB, Aggarwal BB. Resveratrol: A multitargeted agent for age-associated chronic diseases. Cell Cycle 2008; 7: 1020-35

28 Kundu JK, Shin YK, Surh YJ. Resveratrol modulates phorbol ester-induced pro-inflammatory signal transduction pathways in mouse skin in vivo: NF-kappaB and AP-1 as prime targets. Biochem Pharmacol 2006; 72: 1506-15
29 Lagouge M, Argmann C, Gerhart-Hines Z, Meziane H, Lerin C, Daussin F et al. Resveratrol Improves mitochondrial function and protects against metabolic disease by activating SIRT1 and PGC-1alpha. Cell 2006; 127: 1109-22

30 Kim D, Nguyen MD, Dobbin MM, Fischer A, Sananbenesi F, Rodgers JT et al. SIRT1 deacetylase protects against neurodegeneration in models for Alzheimer's disease and amyotrophic lateral sclerosis. Embo J 2007; 26: 3169-79

31 Hayashibara T, Yamada Y, Nakayama S, Harasawa H, Tsuruda K, Sugahara $K$ et al. Resveratrol induces downregulation in survivin expression and apoptosis in HTLV-1-infected cell lines: a prospective agent for adult T cell leukemia chemotherapy. Nutr Cancer 2002; 44: $193-201$

32 Shankar S, Singh G, Srivastava RK. Chemoprevention by resveratrol: molecular mechanisms and therapeutic potential. Front Biosci 2007; 12: $4839-54$

33 Lee SC, Chan J, Clement MV, Pervaiz S. Functional proteomics of resveratrol-induced colon cancer cell apoptosis: caspase-6-mediated cleavage of lamin A is a major signaling loop. Proteomics 2006; 6: 2386-94

34 Delmas D, Rebe C, Lacour S, Filomenko R, Athias A, Gambert P et al. Resveratrol-induced apoptosis is associated with Fas redistribution in the rafts and the formation of a death-inducing signaling complex in colon cancer cells. J Biol Chem 2003; 278: 41482 -90

35 Su JL, Lin MT, Hong CC, Chang CC, Shiah SG, Wu CW et al. Resveratrol induces FasL-related apoptosis through Cdc42 activation of ASK1/ JNK-dependent signaling pathway in human leukemia HL-60 cells. Carcinogenesis 2005; 26: 1 - 10

36 Tsan MF, White JE, Maheshwari JG, Bremner TA, Sacco J. Resveratrol induces Fas signalling-independent apoptosis in THP-1 human monocytic leukaemia cells. Br J Haematol 2000; 109: 405-12

37 Bernhard D, Tinhofer I, Tonko M, Hubl H, Ausserlechner MJ, Greil R et al. Resveratrol causes arrest in the S-phase prior to Fas-independent apoptosis in CEM-C7H2 acute leukemia cells. Cell Death Differ 2000; 7: $834-42$

38 Fulda S, Debatin KM. Resveratrol-mediated sensitisation to TRAIL-induced apoptosis depends on death receptor and mitochondrial signalling. Eur J Cancer 2005; 41: 786-98

39 Clement MV, Hirpara JL, Chawdhury SH, Pervaiz S. Chemopreventive agent resveratrol, a natural product derived from grapes, triggers CD95 signaling-dependent apoptosis in human tumor cells. Blood 1998; 92: 996- 1002

40 Wang Y, Wang B, Cheng J, Yang L, Liu ZL, Balan K et al. FADD-dependent apoptosis induction in Jurkat leukemia T-cells by the resveratrol analogue, 3,4,5-trihydroxy-trans-stilbene. Biochem Pharmacol 2005; 69: $249-54$

41 Kundu JK, Chun KS, Kim SO, Surh YJ. Resveratrol inhibits phorbol esterinduced cyclooxygenase-2 expression in mouse skin: MAPKs and AP1 as potential molecular targets. Biofactors 2004; $21: 33-9$

42 Aggarwal BB, Shishodia S. Molecular targets of dietary agents for prevention and therapy of cancer. Biochem Pharmacol 2006; 71: 1397 421

43 Yu R, Hebbar V, Kim DW, Mandlekar S, Pezzuto JM, Kong AN. Resveratrol inhibits phorbol ester and UV-induced activator protein 1 activation by interfering with mitogen-activated protein kinase pathways. Mol Pharmacol 2001; 60: 217-24

44 Frojdo S, Cozzone D, Vidal H, Pirola L. Resveratrol is a class IA phosphoinositide 3-kinase inhibitor. Biochem J 2007; 406: 511 -8

45 Pozo-Guisado E, Lorenzo-Benayas MJ, Fernandez-Salguero PM. Resveratrol modulates the phosphoinositide 3-kinase pathway through an estrogen receptor alpha-dependent mechanism: relevance in cell proliferation. Int J Cancer 2004; 109: 167 - 73

46 Inoue $H$, Jiang XF, Katayama T, Osada S, Umesono $K$, Namura S. Brain protection by resveratrol and fenofibrate against stroke requires peroxisome proliferator-activated receptor alpha in mice. Neurosci Lett 2003; 352: $203-6$

47 Bowers JL, Tyulmenkov VV, Jernigan SC, Klinge CM. Resveratrol acts as a mixed agonist/antagonist for estrogen receptors alpha and beta. Endocrinology 2000; 141: 3657-67

48 Mueller SO, Simon S, Chae K, Metzler M, Korach KS. Phytoestrogens and their human metabolites show distinct agonistic and antagonistic properties on estrogen receptor alpha (ERalpha) and ERbeta in human cells. Toxicol Sci 2004; 80: 14-25

49 Wada-Hiraike 0, Warner M, Gustafsson JA. New developments in oestrogen signalling in colonic epithelium. Biochem Soc Trans 2006; 34: $1114-6$ 
50 Kundu JK, Shin YK, Kim SH, Surh YJ. Resveratrol inhibits phorbol esterinduced expression of COX-2 and activation of NF-kappaB in mouse skin by blocking IkappaB kinase activity. Carcinogenesis 2006; 27: $1465-74$

51 Suh N, Paul S, Hao X, Simi B, Xiao H, Rimando AM et al. Pterostilbene, an active constituent of blueberries, suppresses aberrant crypt foci formation in the azoxymethane-induced colon carcinogenesis model in rats. Clin Cancer Res 2007; 13: 350 - 5

52 Hougee S, Faber J, Sanders A, de Jong RB, van den Berg WB, Garssen J et al. Selective COX-2 inhibition by a Pterocarpus marsupium extract characterized by pterostilbene, and its activity in healthy human volunteers. Planta Med 2005; 71: 387 - 92

53 Subbaramaiah K, Dannenberg AJ. Resveratrol inhibits the expression of cyclooxygenase- 2 in mammary epithelial cells. Adv Exp Med Biol 2001; 492: 147 - 57

54 Subbaramaiah K, Chung WJ, Michaluart P, Telang N, Tanabe T, Inoue $H$ et al. Resveratrol inhibits cyclooxygenase-2 transcription and activity in phorbol ester-treated human mammary epithelial cells. J Biol Chem 1998; 273: $21875-82$

55 Das S, Fraga CG, Das DK. Cardioprotective effect of resveratrol via HO-1 expression involves p38 map kinase and PI-3-kinase signaling, but does not involve NFkappaB. Free Radic Res 2006; 40: 1066- 75

56 Chun YJ, Kim MY, Guengerich FP. Resveratrol is a selective human cytochrome P450 1A1 inhibitor. Biochem Biophys Res Commun 1999; 262: $20-4$

57 Mikstacka R, Rimando AM, Szalaty K, Stasik K, Baer-Dubowska W. Effect of natural analogues of trans-resveratrol on cytochromes P4501A2 and 2E1 catalytic activities. Xenobiotica 2006; 36: 269-85

58 Mikstacka R, Przybylska D, Rimando AM, Baer-Dubowska W. Inhibition of human recombinant cytochromes P450 CYP1A1 and CYP1B1 by trans-resveratrol methyl ethers. Mol Nutr Food Res 2007; 51: 517-24

59 Belleri M, Ribatti D, Nicoli S, Cotelli F, Forti L, Vannini V et al. Antiangiogenic and vascular-targeting activity of the microtubule-destabilizing trans-resveratrol derivative 3,5,4'-trimethoxystilbene. Mol Pharmacol 2005; 67: 1451 - 9

60 Banerjee S, Bueso-Ramos C, Aggarwal BB. Suppression of 7,12-dimethylbenz $[a]$ anthracene-induced mammary carcinogenesis in rats by resveratrol: role of nuclear factor-kappaB, cyclooxygenase 2 , and matrix metalloprotease 9. Cancer Res 2002; 62: 4945 - 54

61 Oak MH, El Bedoui J, Schini-Kerth VB. Antiangiogenic properties of natural polyphenols from red wine and green tea. J Nutr Biochem 2005; 16: $1-8$

62 Chen Y, Tseng SH. Review. Pro- and anti-angiogenesis effects of resveratrol. In Vivo 2007; 21: 365 - 70

63 Howitz KT, Bitterman KJ, Cohen HY, Lamming DW, Lavu S, Wood JG et al. Small molecule activators of sirtuins extend Saccharomyces cerevisiae lifespan. Nature 2003; 425: 191 - 6

64 Walle T, Hsieh F, DeLegge MH, Oatis JE Jr, Walle UK. High absorption but very low bioavailability of oral resveratrol in humans. Drug Metab Dispos 2004; 32: $1377-82$

65 Goldberg DM, Yan J, Soleas GJ. Absorption of three wine-related polyphenols in three different matrices by healthy subjects. Clin Biochem 2003; 36: $79-87$

66 Yu C, Shin YG, Chow A, Li Y, Kosmeder JW, Lee YS et al. Human, rat, and mouse metabolism of resveratrol. Pharm Res 2002; 19: 1907-14

67 Remsberg CM, Yanez JA, Ohgami Y, Vega-Villa KR, Rimando AM, Davies NM. Pharmacometrics of pterostilbene: preclinical pharmacokinetics and metabolism, anticancer, anti-inflammatory, antioxidant and analgesic activity. Phytother Res 2008; 22: 169 - 79

68 Roupe KA, Yanez JA, Teng XW, Davies NM. Pharmacokinetics of selected stilbenes: rhapontigenin, piceatannol and pinosylvin in rats. J Pharm Pharmacol 2006; 58: 1443 - 50

69 Marier JF, Vachon P, Gritsas A, Zhang J, Moreau JP, Ducharme MP. Metabolism and disposition of resveratrol in rats: extent of absorption, glucuronidation, and enterohepatic recirculation evidenced by a linked-rat model. J Pharmacol Exp Ther 2002; 302: 369-73

70 Aziz MH, Afaq F, Ahmad N. Prevention of ultraviolet-B radiation damage by resveratrol in mouse skin is mediated via modulation in survivin. Photochem Photobiol 2005; 81: 25-31

71 Afaq F, Adhami VM, Ahmad N. Prevention of short-term ultraviolet B radiation-mediated damages by resveratrol in SKH-1 hairless mice. Toxicol Appl Pharmacol 2003; 186: 28 - 37

72 Kapadia GJ, Azuine MA, Tokuda H, Takasaki M, Mukainaka T, Konoshima $T$ et al. Chemopreventive effect of resveratrol, sesamol, sesame oil and sunflower oil in the Epstein-Barr virus early antigen activation assay and the mouse skin two-stage carcinogenesis. Pharmacol Res 2002; 45: 499-505

73 Li ZG, Hong T, Shimada Y, Komoto I, Kawabe A, Ding Y et al. Suppression of $\mathrm{N}$-nitrosomethylbenzylamine (NMBA)-induced esophageal tumorigenesis in F344 rats by resveratrol. Carcinogenesis 2002; 23: $1531-6$

74 Provinciali M, Re F, Donnini A, Orlando F, Bartozzi B, Di Stasio G et al Effect of resveratrol on the development of spontaneous mammary tumors in HER-2/neu transgenic mice. Int J Cancer 2005; 115: 36 - 45

75 Whitsett T, Carpenter M, Lamartiniere CA. Resveratrol, but not EGCG, in the diet suppresses DMBA-induced mammary cancer in rats. J Carcinog 2006; 5: 15

76 Coussens LM, Werb Z. Inflammation and cancer. Nature 2002; 420 $860-7$

77 Ulrich CM, Bigler J, Potter JD. Non-steroidal anti-inflammatory drugs for cancer prevention: promise, perils and pharmacogenetics. Nat Rev Cancer 2006; 6: $130-40$

78 Ohta T, Takahashi M, Ochiai A. Increased protein expression of both inducible nitric oxide synthase and cyclooxygenase- 2 in human colon cancers. Cancer Lett 2006; 239: 246-53

79 Cianchi F, Cortesini C, Fantappie O, Messerini L, Schiavone N, Vannacci A et al. Inducible nitric oxide synthase expression in human colorectal cancer: correlation with tumor angiogenesis. Am J Pathol 2003; 162: $793-801$

80 Rao CV, Kawamori T, Hamid R, Reddy BS. Chemoprevention of colonic aberrant crypt foci by an inducible nitric oxide synthase-selective inhibitor. Carcinogenesis 1999; 20: 641 - 4

81 Takahashi M, Mutoh M, Shoji Y, Sato H, Kamanaka Y, Naka M et al. Suppressive effect of an inducible nitric oxide inhibitor, ONO-1714, on AOM-induced rat colon carcinogenesis. Nitric Oxide 2006; 14: 130-6

82 Rao CV, Indranie C, Simi B, Manning PT, Connor JR, Reddy BS. Chemopreventive properties of a selective inducible nitric oxide synthase inhibitor in colon carcinogenesis, administered alone or in combination with celecoxib, a selective cyclooxygenase-2 inhibitor. Cancer Res 2002; 62: $165-70$

83 Tessitore L, Davit A, Sarotto I, Caderni G. Resveratrol depresses the growth of colorectal aberrant crypt foci by affecting bax and p21(CIP) expression. Carcinogenesis 2000; 21: 1619-22

84 Sengottuvelan $M$, Viswanathan $P$, Nalini $N$. Chemopreventive effect of trans-resveratrol - a phytoalexin against colonic aberrant crypt foci and cell proliferation in 1,2-dimethylhydrazine induced colon carcinogenesis. Carcinogenesis 2006; 27: 1038 - 46

85 Corpet DE, Pierre F. Point: From animal models to prevention of colon cancer. Systematic review of chemoprevention in min mice and choice of the model system. Cancer Epidemiol Biomarkers Prev 2003; 12 : $391-400$

86 Schneider Y, Duranton B, Gosse F, Schleiffer R, Seiler N, Raul F. Resveratrol inhibits intestinal tumorigenesis and modulates host-defense-related gene expression in an animal model of human familial adenomatous polyposis. Nutr Cancer 2001; 39: $102-7$

87 Ziegler CC, Rainwater L, Whelan J, McEntee MF. Dietary resveratrol does not affect intestinal tumorigenesis in $\operatorname{Apc}(\operatorname{Min} /+)$ mice. J Nutr 2004; 134: $5-10$

88 Sale S, Tunstall RG, Ruparelia KC, Potter GA, Steward WP, Gescher AJ. Comparison of the effects of the chemopreventive agent resveratrol and its synthetic analog trans-3,4,5,4'-tetramethoxystilbene (DMU212) on adenoma development in the $\mathrm{Apc}(\mathrm{Min}+)$ mouse and cyclooxygenase- 2 in human-derived colon cancer cells. Int J Cancer 2005; 115: $194-201$

89 Kineman BD, Au A, Paiva NL, Kaiser MS, Brummer EC, Birt DF. Transgenic alfalfa that accumulates piceid (trans-resveratrol-3-O-beta-D-glucopyranoside) requires the presence of beta-glucosidase to inhibit the formation of aberrant crypt foci in the colon of CF-1 mice. Nutr Cancer 2007; 58: $66-74$

90 Jang M, Cai L, Udeani GO, Slowing KV, Thomas CF, Beecher CW et al. Cancer chemopreventive activity of resveratrol, a natural product derived from grapes. Science 1997; 275: $218-20$

91 Zern TL, Wood RJ, Greene C, West KL, Liu Y, Aggarwal D et al. Grape polyphenols exert a cardioprotective effect in pre- and postmenopausal women by lowering plasma lipids and reducing oxidative stress. J Nutr 2005; 135: 1911 - 7

92 Levi F, Pasche C, Lucchini F, Ghidoni R, Ferraroni M, La Vecchia C. Resveratrol and breast cancer risk. Eur J Cancer Prev 2005; 14: 139-42

93 Boocock DJ, Faust GE, Patel KR, Schinas AM, Brown VA, Ducharme MP et al. Phase I dose escalation pharmacokinetic study in healthy volun- 
teers of resveratrol, a potential cancer chemopreventive agent. Cancer Epidemiol Biomarkers Prev 2007; 16: 1246 - 52

94 Manners GD, Swan EP. Stilbenes in the barks of five Canadian Picea species. Phytochemistry 1971; 10: 607-10

95 Waffo-Teguo P, Hawthorne ME, Cuendet M, Merillon JM, Kinghorn AD, Pezzuto JM et al. Potential cancer-chemopreventive activities of wine stilbenoids and flavans extracted from grape (Vitis vinifera) cell cultures. Nutr Cancer 2001; 40: 173-9

96 Wober J, Moller F, Richter T, Unger C, Weigt C, Jandausch A et al. Activation of estrogen receptor-beta by a special extract of Rheum rhaponticum (ERr 731), its aglycones and structurally related compounds. J Steroid Biochem Mol Biol 2007; 107: 191 - 201

97 Ko SK. Effects of stilbene derivatives from Rheum undulatum on 5a-reductase activity. Saengyak Hakhoechi 2000; 31: $245-8$

98 Ryu SY, Choi SU, Lee CO, Lee SH, Ahn JW, Zee OP. Antitumor activity of some phenolic components in plants. Arch Pharm Res 1994; 17: $42-4$

99 Mellanen P, Petanen T, Lehtimaki J, Makela S, Bylund G, Holmbom B et al. Wood-derived estrogens: studies in vitro with breast cancer cell lines and in vivo in trout. Toxicol Appl Pharmacol 1996; 136: 381 -8

100 Deshpande VH, Srinivasan R, Rao AVR. Wood phenolics of Morus species. IV. Phenolics of the heartwood of five Morus species. Indian J Chem 1975; 13: $453-7$

101 Lee SK, Nam KA, Hoe YH, Min HY, Kim EY, Ko H et al. Synthesis and evaluation of cytotoxicity of stilbene analogues. Arch Pharm Res 2003; $26: 253-7$

102 Kim YH, Park C, Lee JO, Kim GY, Lee WH, Choi YH et al. Induction of apoptosis by piceatannol in human leukemic U937 cells through down-regulation of $\mathrm{Bcl}-2$ and activation of caspases. Oncol Rep 2008; 19: $961-7$

103 Kuo PL, Hsu YL. The grape and wine constituent piceatannol inhibits proliferation of human bladder cancer cells via blocking cell cycle progression and inducing Fas/membrane bound Fas ligand-mediated apoptotic pathway. Mol Nutr Food Res 2008; 52: 408-18

104 Waterhouse AL, Lamuela-Raventos RM. The occurrence of piceid, a stilbene glucoside, in grape berries. Phytochemistry 1994; 37: 571 -3

105 Tyukavkina NA, Gromova AS, Lutskii VI, Voronov VK. Hydroxystilbenes from Pinus sibirica bark. Khimiya Prirodnykh Soedinenii 1972; 5: $600-3$
106 Gromova AS, Lutskii VI, Tyukavkina NA. Stilbenes from the bark of some Pinaceae species. Koksnes Kimija 1979; 3: 103-9

107 Clausen TP, Reichardt PB, Bryant JP. Pinosylvin and pinosylvin methyl ether as feeding deterrents in green alder. J Chem Ecol 1986; 12: 2117-31

108 Jorgensen $E$. The formation of pinosylvin and its monomethyl ether in the sapwood of Pinus resinosa. Can J Bot 1961; 39: 1765 - 72

109 Skinnider L, Stoessl A. The effect of the phytoalexins, lubimin, (-)maackiain, pinosylvin, and the related compounds dehydroloroglossol and hordatine $\mathrm{M}$ on human lymphoblastoid cell lines. Experientia 1986; 42: $568-70$

110 Pezet $R$, Pont $V$. Demonstration of pterostilbene in clusters of Vitis vinifera. Plant Physiol Biochem 1988; 26: 603-7

111 Maurya R, Ray AB, Duah FK, Slatkin DJ, Schiff PL Jr. Constituents of Pterocarpus marsupium. J Nat Prod 1984; 47: 179-81

112 MacRae WD, Towers GHN. Nonalkaloidal constituents of Virola elongata bark. Phytochemistry 1985; 24: $561-6$

113 Cardile V, Chillemi R, Lombardo L, Sciuto S, Spatafora C, Tringali C. Antiproliferative activity of methylated analogues of $E$ - and Z-resveratrol. Z Naturforsch [C] 2007; 62: 189-95

114 Murakami T, Tanaka K. New phenolic glycosides in Rhei palmati rhizomes. Tetrahedron Lett 1972; 29: $2965-8$

115 Ferrer P, Asensi M, Segarra R, Ortega A, Benlloch M, Obrador E et al. Association between pterostilbene and quercetin inhibits metastatic activity of B16 melanoma. Neoplasia 2005; 7: 37 - 47

116 Asensi M, Medina I, Ortega A, Carretero J, Bano MC, Obrador E et al. Inhibition of cancer growth by resveratrol is related to its low bioavailability. Free Radic Biol Med 2002; 33: 387 - 98

117 Sengottuvelan $M$, Nalini $N$. Dietary supplementation of resveratrol suppresses colonic tumour incidence in 1,2-dimethylhydrazine-treated rats by modulating biotransforming enzymes and aberrant crypt foci development. Br J Nutr 2006; 96: $145-53$

118 Pan MH, Gao JH, Lai CS, Wang YJ, Chen WM, Lo CY et al. Antitumor activity of 3,5,4'-trimethoxystilbene in COLO 205 cells and xenografts in SCID mice. Mol Carcinogen 2008; 47: 184-96

119 Martin AR, Villegas I, Sanchez-Hidalgo M, de la Lastra CA. The effects of resveratrol, a phytoalexin derived from red wines, on chronic inflammation induced in an experimentally induced colitis model. $\mathrm{Br}$ Pharmacol 2006; 147: 873-85 